\title{
Clam hunger and the changing ocean: characterizing social and ecological risks to the Quinault razor clam fishery using participatory modeling
}

\author{
$\underline{\text { Katherine M. Crosman }}^{1}$, Eleni L. Petrou ${ }^{2}$, Merrill B. Rudd ${ }^{2,3}$ and Michael D. Tillotson $^{2,4}$
}

\begin{abstract}
On the outer coast of Washington state, traditional lifestyles are closely entwined with the marine resources affected by ocean change, e.g., ocean warming, ocean acidification, fishing, coastal development, etc. Our research explores how ongoing ocean change may challenge the social-ecological system surrounding the Quinault Indian Nation's razor clam (Siliqua patula) harvest. We conducted semistructured interviews with Quinault tribal members, scientists, and resource managers to build a conceptual model of the social-ecological system, which we use to (1) understand the emergent effects of changes in availability of razor clams and (2) explore how the tribal community might prepare for or adapt to these changes. Razor clams are a staple food and key source of income for the Quinault people because of their lasting abundance, low cost to harvest, and long season of availability relative to other natural resources. Lower income families experience disproportionate economic impacts during razor clam harvest closures, but less tangible social and cultural impacts are felt broadly throughout the community. Although razor clams have been, in general, available and safe for harvest in recent years, the Quinault people perceive many threats to the resource, including climate change, harmful algal blooms, pollution, and habitat loss. We used the perceived risks identified from the interview results, along with peer-reviewed scientific literature, to develop several ocean change scenarios. Using a stage-based population model of the Pacific razor clam, we explored the relative impacts of these scenarios on annual razor clam harvest over a 20 -year period. The simulation of scenarios was developed into a userfriendly web-based application as a planning tool for the Quinault Indian Nation, to help them explore connections between ocean change and razor clam availability, and to support their efforts to plan for and adapt to the impacts of change.
\end{abstract}

Key Words: coastal communities; ocean change; participatory modeling; razor clams; risk identification; social-ecological systems

\section{INTRODUCTION}

Rural and remote coastal communities are uniquely vulnerable to multiple processes of environmental change (Bennett et al. 2016). These communities are often economically vulnerable because they are commonly resource-dependent and rely on exploitation of coastal and marine resources or nature-based tourism (Dyson and Huppert 2010). They may also be physically vulnerable to climate change impacts such as sea level rise, increased storm activity, and loss of sea ice (Schwarz et al. 2011). Both economic and physical vulnerabilities may have cascading impacts when interacting with the greater social-ecological system (Holling 2001). Thus, the myriad risks facing marine resources, including warming water, ocean acidification, pollution, coastal development, and resource overexploitation, can also threaten coastal communities (Dolan and Walker 2006). Small coastal communities may also have limited resilience to environmental change; identifying likely changes and their impacts may help these communities prepare and adapt.

Many coastal communities are home to fundamentally placebased societies, and have rich histories of adapting to past environmental fluctuations and change (Wolf et al. 2013). This is particularly true for indigenous communities, many of which have continuously inhabited coastal spaces for millennia (Turner and Clifton 2009, Petheram et al. 2010). However, in North America, the arrival of European colonizers upset traditional adaptive strategies. For example, laws confining indigenous harvest activities to reservations or "usual and accustomed" areas (Silvern 1999) prevent U.S. tribal populations from using resources from a variety of geographic areas or switching between resources, both of which were traditional responses to resource fluctuations
(Berkes and Jolly 2002). The livelihoods, history, and place attachment of such communities also prevent them from simply relocating in the face of resource loss. Finally, tribal communities in the U.S. commonly face economic challenges (Cornell and Kalt 1998), stretching their resources and adaptive capacity. These realities, coupled with the complexity of the changes these communities face, are likely to make understanding and preparing for future change particularly challenging (Dolan and Walker 2006).

There is significant global interest in the processes of adaptation in complex social-ecological systems (SES; Holling 2001, Walker et al. 2004, Ostrom 2009, Hinkel et al. 2014). Although frameworks of SES dynamics are now well established (Ostrom 2009, Ostrom and Cox 2010, Epstein et al. 2013), the impacts of environmental change on coastal communities are nevertheless highly context dependent, and case studies are necessary to test and refine theory in real world settings (Kittinger et al. 2012). Furthermore, given the anticipated impacts of ocean change on coastal indigenous communities, tribal governments, resource managers, and community members seek to identify strategies that can increase economic, social, and cultural resilience (Berkes and Jolly 2002, Tschakert 2007, Petheram et al. 2010, Swinomish Indian Tribal Community 2010).

Participatory modeling holds promise for informing locally appropriate adaptation strategies by integrating disparate knowledge sources and engaging communities in the research process (Tansey et al. 2002, van Aalst et al. 2008, Shaw et al. 2009). Models can help describe a system by identifying interacting components and making predictions about system behavior using

${ }^{1}$ University of Washington, Daniel J. Evans School of Public Policy and Governance, ${ }^{2}$ University of Washington, School of Aquatic and Fishery Sciences, ${ }^{3}$ Scaleability LLC, ${ }^{4}$ Gulf of Maine Research Institute 
Fig. 1. Map of the study region showing the Quinault Indian Nation's reservation lands and primary razor clamming (Siliqua patula) beaches. The small insert on the map shows Washington State, USA; the study site is outlined in a yellow rectangle. Allowable and realized catches for three comanaged, off-reservation beaches are shown in the panels on the left.

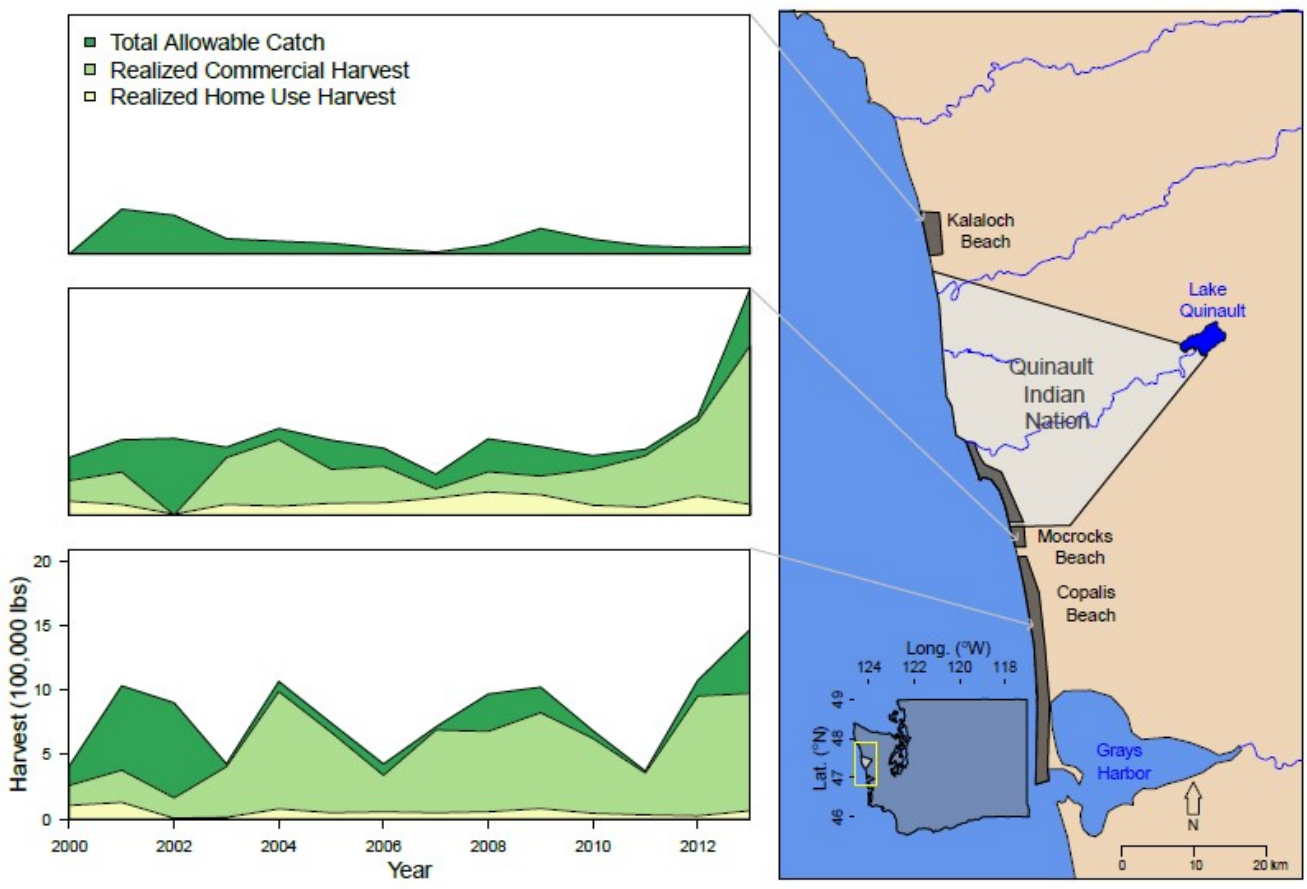

mathematical concepts or words. In describing a natural resource SES, natural scientists hold specialized knowledge about the processes of physical and ecological change that may be poorly understood within nonscientific communities. On the other hand, community members, resources users, local governments, and resource managers hold fine-grained knowledge of local environments and ecologies, as well as specialized knowledge about economic, social, and cultural systems and localized responses to past environmental variability (Turner and Clifton 2009). A participatory approach can therefore act as a two-way transfer of knowledge and inform robust conceptual models of complex SES. These models can then be used to explore system dynamics in response to perturbations, for example, using scenarios to explore the social-ecological impacts associated with reduced abundance of a valuable resource or loss of access to an important market (Cinner et al. 2011). Because predicting future states of complex SES is inherently a highly uncertain process, this type of scenario-based approach can help to explore responses to a range of possible future states (Evans et al. 2013).

In this study we seek to investigate the following question: "How will a resource-dependent coastal community be impacted by, and adapt to, ocean change?" For the purposes of this study, we define ocean change as any anthropogenic change to the marine or coastal environment, including climate-related changes such as ocean acidification and changes in water temperature (Hauser et al. 2016), but also other anthropogenic changes such as pollution, fishing, and coastal development. To answer this question, we used individual and group interviews to build a conceptual model of the SES surrounding a key marine resource in a remote, indigenous coastal community in Washington State, USA. Our conceptual model focused on economic, livelihood, governance, and institutional components and relationships. Subsequently, community interview participants identified risks they perceive to the natural resource system. We used the resulting data to create a web-based simulation tool to help the community prepare for change by connecting their perceived risks with the expected biological impacts of each risk, and how those risks may impact the population individually and in tandem (when multiple risks interact with each other and impact the population at the same time).

\section{METHODS}

\section{Study social-ecological system}

We took a case-based approach to our research question, partnering with the Quinault Indian Nation (QIN) to focus our study on the SES linking the Quinault and the Pacific razor clam (Siliqua patula). Focusing on a single SES allowed us to gain an in-depth understanding of resource use and importance as well as relevant local institutional structures and governance, and to situate that understanding within its local context.

\section{The Quinault Indian Nation}

The QIN is a federally recognized, self-regulating sovereign nation on the central Pacific coast of Washington State (Fig. 1; James and Chubby 2002). The QIN consists of members and descendants of seven coastal tribes, including the Quinault, Queets, Quileute, Hoh, Chehalis, Chinook, and Cowlitz; here, 
when we refer to "the Quinault," we are referring to members of the Quinault Indian Nation rather than to only members of the Quinault tribe. Approximately 3100 people are enrolled in the QIN; of those, approximately $50 \%$ live on the Quinault reservation (Gustanski and Scarsella 2015).

The Quinault reservation is located on the southern end of the Olympic Peninsula on the central Washington coast. It was established via the Treaty of Olympia in 1865 and later enlarged by the Executive Order of 4 November 1873, with the intent to include "other tribes of fish-eating Indians on the Pacific Coast," many of which currently make up the QIN (Porter 1990). Taholah, the commercial and residential center of the reservation, is relatively remote: it is essentially inaccessible by road from the north, and accessible only by forest roads from the east. The primary point of access is from the south via a two-lane state road. The nearest city is Ocean Shores, Washington (population 5831 in 2016 , approximately 28 miles by road to the south of Taholah). The reservation was established by executive order in 1873 and subsequently expanded, currently encompassing over 200,000 acres of productive forests, rivers, lakes, and beaches (James and Chubby 2002). Like many isolated rural areas, and in common with other Native American reservations, the Quinault reservation faces economic challenges including high unemployment and low median income compared with nearby communities (Cornell and Kalt 1998, Gustanski and Scarsella 2015). The reservation economy is dominated by the natural resource and government services sectors; many individuals engage in a mix of seasonal work and subsistence harvest. The QIN owns a variety of businesses that employ tribal members, including Quinault Pride Seafoods, a seafood processing facility that purchases the majority of the tribal harvest. The Quinault Business Committee, responsible for the day-to-day management of Nation affairs, granted us formal approval to conduct our research.

\section{The Pacific razor clam}

The Pacific razor clam is distributed from California to Alaska (Lassuy and Simons 1989). Adult clams are found buried in the intertidal and subtidal zone of open coast sandy beaches, where they feed on surf zone phytoplankton. In Washington State, razor clams spawn in late spring and early summer. After spending a planktonic stage of approximately 10 weeks in the water column, larvae develop into juveniles that are then capable of settling onto sand. Juvenile clams are eaten by shorebirds, fish, Dungeness crabs (Cancer magister), and other species, while adult clams are eaten by sea otters (Enhydra lutris) and humans. Many aspects of razor clam biology remain unknown (e.g., survival rates of larvae, juveniles and adults; density dependent mortality; duration of juvenile period; population connectivity). Additionally, existing data are often from decades-old studies and/or not published in the peer-reviewed scientific literature. Despite these uncertainties, Washington's razor clam fisheries have provided consistent commercial and noncommercial harvest for decades (Fig. 1; Wyer 2013).

\section{System history and context}

In 1974, in response to a history of conflict over indigenous rights to traditional resources, the Boldt decision recognized tribal treaty rights to salmon in Washington State, and mandated comanagement between the state and the tribes. The 1994
Rafeedie decision extended the mandate to shellfish and reaffirmed the rights to halibut (Hippoglossus stenolepis), sablefish (Anoplopoma fimbria), rockfish, and other marine species. Under the terms of the Rafeedie decision, the Quinault are entitled to $50 \%$ of the total allowable razor clam catch along 58 miles of Washington Pacific coast beaches (Anderson 1999) and rights to $100 \%$ of razor clams on the reservation beaches.

The Quinault currently harvest razor clams for both home and commercial use, but Quinault use of razor clams stretches back to time immemorial. An ethnographic study (Olson 1936) reports that razor clams (haitssaw'us) were an important food item and that "Dozens of families moved to these places every summer to dry clams for the winter's supply. It is said that the shell heaps at Copalis are miles long and many feet deep." Clams are also featured in Quinault myths, such as the story of Misp', which was documented in the early 20 th century (Livingston and Kahnweiler 1975:85):

Misp' next came to Copalis River and called the people;
and they came out upside down, with nothing but small
flounder-spears and short sticks for digging clams. And
he told them that such should be their work; and after
turning them right side up he left them. And the people
of Copalis River have lived on small fish and clams ever
since.

The Quinault are responsible for the vast majority of commercial razor clam harvest and sales in Washington State. The commercial fishery has in recent years provided over $\$ 600,000$ of annual income to clam diggers while subsistence harvests provide food throughout the year (Gustanski and Scarsella 2015). Under the current comanagement regime, the Quinault razor clam fishery is well-managed, with controlled beach access during specific harvest tides and minimal harvest outside of the officially sanctioned windows (Wyer 2013).

\section{Interview methods}

We conducted four multiday visits to the Quinault reservation between March 2014 and September 2016. At the time of our study, the Quinault were experiencing an unprecedented closure of their coastal fisheries, including razor clams, because of high levels of domoic acid associated with a harmful algal bloom (HAB) that impacted much of the West Coast (McCabe et al. 2016). The purpose of our first visit was to establish rapport with local shellfish managers and tribal leaders; the second and third visits focused on semistructured key informant and group interviews, respectively. In the final visit, we reported initial findings and sought comments on our preliminary results in a community meeting.

Our semistructured interview approach was grounded in Ostrom's (2009) framework for the study of sustainability in SES. With input from our local contacts, we iteratively operationalized the key components of Ostrom's framework into interview questions, and then assigned each question to the key informant or group interview script based on the nature of respondent expertise required (Appendices 1 and 2).

We selected key informants based on their professional and/or personal standing in the community, particularly on access to specialized information on razor clam management and Quinault history and institutions. Key informant interviews focused on the 
institutions structuring the Quinault's use of razor clams. Questions for key informants targeted tribal and comanagement resource governance structures, the distribution of clams and economic benefits of the clam harvest through the community, specification of property rights to clams, harvest monitoring and enforcement structures, conflict and conflict resolution, historical changes, and change in harvest over recent years (Appendix 1). We solicited key informants through local contacts and supplemented our initially identified key informants through snowball sampling. In accordance with tribal norms, we provided key informants with either a gift card or a small nonmonetary gift (when position or title precluded monetary compensation). Interviews lasted between 26 and 92 minutes. We conducted 10 interviews with key informants including resource managers, tribal officials, tribal elders, seafood processors, and seafood buyers.

We recruited participants in group interviews from Quinault community members more broadly, grouping participants by their use of razor clams as well as demographic characteristics. Group interviews focused on individual and community histories of razor clam use; seasonal trends in availability and use of clams and other subsistence resources; fishery entry costs and sources of equipment; norms, communication, and social capital associated with razor clam use; individual and community importance of razor clams for food, income, and other benefits; and perceived risks to razor clams and razor clam harvests (Appendix 2). Group interview participants were solicited through flyers posted at community meeting points and by wordof-mouth. Participants were provided with a gift card to thank them for their participation. Group interviews lasted between 40 and 60 minutes. We conducted seven group interviews with (1) commercial and (2) subsistence clammers, (3) razor clam processors, (4) razor clam buyers, (5) commercial fishers, (6) young adults (specifically recommended for inclusion by key informants), and (7) elders. Our total group interview sample size was 20 participants.

In addition to the interview script, we supplemented group interviews with a seasonal cycle graphic. We used the seasonal cycle graphic to solicit participant input on how razor clams align with other income-generating and subsistence activities over the course of a year. A subset of group interview participants also participated in a risk ranking exercise, where the group collaboratively generated a list of risks to the SES. Individuals then voted on the risks they thought were most important to the QIN.

\section{Analysis}

All key informant and a subset of group interviews were transcribed and coded in Dedoose version 7.0.23 (SocioCultural Research Consultants LLC 2016). Consistent with our interview script, the coding scheme (Appendix 3) was adapted from Ostrom's (2009) SES framework. A single coder analyzed all transcribed interviews and $25 \%$ of transcribed interviews were coded by two people to establish intercoder reliability. Average percent agreement for the double-coded interviews was $89 \%$; average Cohen's kappa was 0.75 . Both measures indicate how well independent coders agree in their application of a shared coding scheme; Cohen's kappa is more robust because it takes into account the possibility that agreement occurred by chance. A kappa of 0.75 indicates good or substantial agreement (Viera and Garrett 2005). Coded interview responses were used to understand the nature of the razor clam resource and its importance to the Quinault, build a conceptual model of the SES, and identify risks perceived by community members.

We used interview responses to develop a preliminary model of the razor clam SES to describe the linkages between the environment, natural resources, institutions, and management and user groups, with particular focus on the benefits that emerge from the system. The initial model was iteratively revised, first through discussions with selected key informants and then during the final community meeting. We identified key stressors to the SES by combining risks discussed in the peer-reviewed scientific literature with community-perceived risks derived from interview responses. We also used these risks, in conjunction with the SES conceptual model, to explore possible adaptive responses to future ocean change.

\section{RESULTS}

Based on our interview findings, we created an initial model of the SES that links razor clams and the Quinault (Fig. 2 shows a simplified version; for the full model see Appendix 4). In general terms, and following accepted methodologies, we conceptualize the system as four linked domains (Collins et al. 2011). The biogeophysical system focuses on extrinsic forces such as water temperature and ocean currents, describing how those forces affect clams and their associated ecosystem. The governance system focuses on how harvests are regulated and managed, including governmental departments and agencies such as the Quinault Division of Natural Resources and the Washington Department of Fish and Wildlife. The resource system focuses on the harvest and drivers of the harvest. Finally, the user domain focuses on how clams and associated benefits propagate through the community.

\section{Benefits from razor clams}

For the most part, our interview questions did not target specific classes of benefits, but instead allowed participants to offer what came first to mind. Consistent with Ostrom's (2009) approach to analyzing SES, our respondents emphasized economic and livelihood benefits from razor clam harvest and use. Also consistent with Ostrom, participants also discussed institutional and social capital benefits associated with razor clams. However, our respondents also drew our attention to myriad benefits that are not specifically addressed by Ostrom's SES framework. These included cultural and Quinault identity benefits and health and well-being benefits. Although our interview questions did not target these classes of benefits specifically, we report them here to accurately reflect the concerns and experience of our respondents.

\section{Economic and livelihood benefits}

Economic and livelihood benefits from the razor clam harvest are widespread. Our participants estimate that approximately half of Quinault members participate directly in the razor clam harvest. Other members benefit indirectly: commercial digs provide not only income for diggers, but also income for workers because the tribally owned seafood processing plant hires additional staff for the season and the profits from the processing plant are cycled back into the community. Finally, much of the income earned by diggers and processors is spent at local, tribally owned businesses. 
Fig. 2. Compressed version of the social-ecological system (SES) conceptual model, structured according to Ostrom's (2009) SES framework and based on interview data (full conceptual model in Appendix 2).QNDR stands for the Quinault Department of Natural Resources.

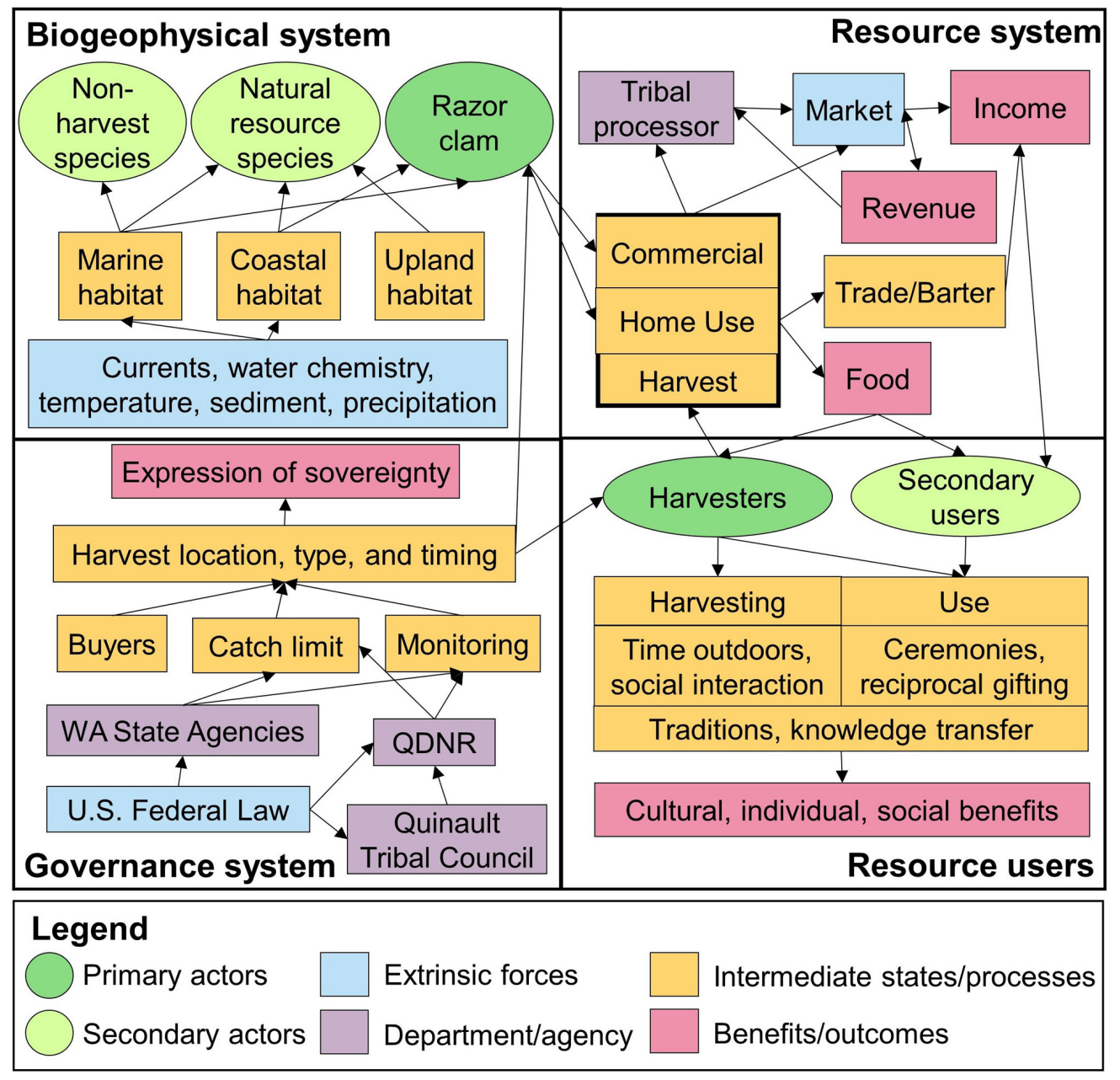

Harvesters' entry and start-up costs are minimal. To participate in a home use (subsistence) dig, tribal members must show only a tribal ID; to participate in a commercial dig, tribal members must secure and display a commercial permit. The latter is free but requires a trip to the Quinault Division of Natural Resources in Taholah. The only gear harvesters require is a clamming shovel and a catch bag (which together cost less than US\$50 new for midrange gear). Transport costs are a minor factor: when digs are scheduled for more distant sites, gas money may be a consideration for some diggers, but ride-sharing is common.

Participants in both key informant and group interviews indicated that razor clam harvests, especially commercial digs, are of particular importance to lower income community members, for whom they provide an economic safety net. Because this is a low entry-cost fishery open to all Quinault tribal members, those who may not be able to participate in other income-generating activities can take part in commercial digs and walk away from the beach with cash in hand. For community members who do have steady incomes from other activities, but who may have little extra income to spare, participation in the commercial harvest helps to make up for shortfalls.

My dad was a clam digger, fisherman, logger, metal worker, clam digging was the way to supplement his income. Back in those days, he would take us on a family trip every year, with just money he made from clam digging. So it was pretty important to the Quinault Nation in that aspect, as a supplement to a person's income, and let them have certain things they otherwise wouldn't be able to get, like family vacation ... a lot of people nowadays use their clam digging ... to buy groceries for their table or school clothes for their kids, so it is really important to the Quinault Nation. (Tribal member)

Razor clams are only one among a suite of natural resources harvested throughout the year by members of the Quinault (Fig. 3 ). Although outweighed in terms of monetary value and harvest volume by other species such as Dungeness crab and salmon (Gustanski and Scarsella 2015), razor clams are nevertheless a 
critical component of the seasonal resource cycle because of the timing of their availability and their accessibility to nearly all of the tribal population. Razor clams are particularly important during the winter months when other resources, especially other resources easily accessed without large capital investment, e.g., wild berries, and alternative employment opportunities are scarce.

Fig. 3. Seasonal cycle of the Quinault Indian Nation's harvested food resources. The cycle highlights the availability of resources harvested for subsistence and commercial use and is based on interview data.

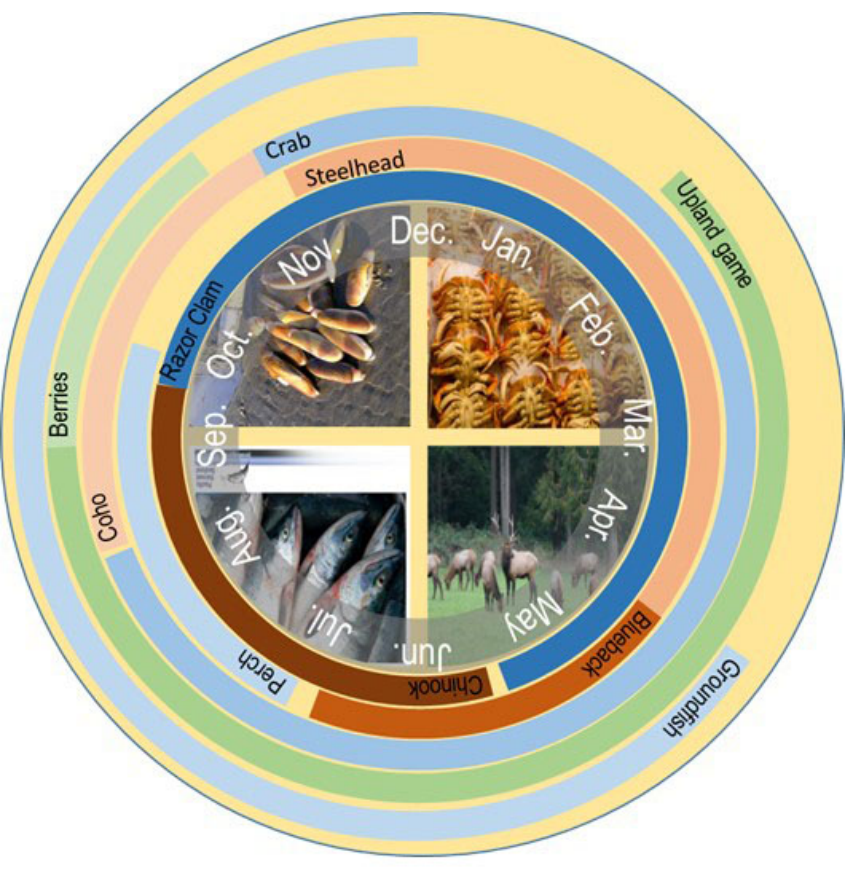

The opening of the clam harvest season typically coincides with the beginning of the school year. Many interview participants mentioned the importance of "back to school" clam digs during which students and families sell clams to purchase clothing and school supplies:

Every year on the reservation at the end of August we open up - not going to be able to do it this year because of the toxins - but we open up a few days on the reservation and they call it school clothes days. And the, all the tribal members come out, all their kids come out and they sit there and dig these clams and usually the clams are not that great of shape and they turn it in to crab bait anyway, but just the fact that they're able to give people cash and money so they can go out and get their school supplies and get new school clothes for all the kids right before it starts. So more like helping out the community than trying to make a buck off the clams. (QDNR employee)

\section{Institutional benefits}

The ongoing act of comanaging the razor clam harvest with Washington State is a recognition of the Quinault's formal status as equal partners in caring for and making decisions about the resources on which they rely. Ongoing comanagement reinforces legal precedents that recognize Quinault tribal sovereignty, and creates institutions and relationships that reinforce Quinault selfgovernance:

\begin{abstract}
We're self-regulating, we make our own regulations, develop them for our tribal membership, it's a jurisdictional issue that we fought with the state over our whole lifetime, and I think if tribal members don't abide by our rules, and by what we implement to safeguard the resource, to safeguard our jurisdiction, and to whatever that could be, we could lose that ability to manage our resource. (Seafood processor)
\end{abstract}

Knowledge transfer and social capital

The act of harvesting and processing razor clams provides an opportunity for intergenerational knowledge transfer, with parents teaching children and grandparents teaching grandchildren about clams, clamming, and the associated ecosystem: "I used to talk about it with my great grandparents. Because they really knew. My great grandpa is the one who taught me how to clean clams" (Elder).

The harvesting and use of clams also create social capital within the community. The act of the harvest, especially home use harvest, leads to multigenerational families clamming together, and induces off-reservation tribal members to return to dig for clams. The use of clams in resource exchange and barter also reinforces social cohesion; for example, we learned that community members might exchange clams for elk meat or other goods. Finally, razor clams are a staple at shared community meals and other community events, e.g., birthdays or funerals, that provide ongoing opportunities to create and maintain social bonds.

\section{Cultural benefits}

In addition to economic, institutional, and social capital benefits, many of our respondents emphasized the importance of razor clams to culture and Quinault identity. For example, "clam hunger" (ta'aWhsi xa'iits'os in the Quinault language) is a concept that was mentioned by multiple interview participants as a cultural reality. We understand it as a deeply felt physical and emotional craving for a traditional food, the harvest of which connects tribal members with traditional places and the eating and sharing of which connects them to their childhoods, their families, and their ancestors. The cultural importance of razor clams is such that being clam hungry may drive individuals to eat clams even when toxin levels are high and fisheries are officially closed.

Indeed, our interview participants place access to, harvest of, and eating razor clams at the heart of Quinault culture and tradition:

I'm 57 years old and I'm a Quinault tribal member. I've been digging clams since I was six years old, and it's part of our tradition and our culture and it's how we've survived for probably way over 10 thousand years in this neck of the woods... And then as far as food, it doesn't get any better than eating a razor clam. I've been eating them my whole life and I can't explain; to me it's better than lobster. (Elder) 
Similarly, clamming reinforces tribal members' sense of being Quinault: "Razor clams are really a rite of passage for us. We learn how to be Quinault on the beach" (Commercial fisher).

\section{Health and well-being benefits}

Our respondents also noted health and well-being benefits from harvesting and eating clams. Clammers noted both the nutritional value of clams when compared to more heavily processed alternatives, and the health benefits of the physical activity of clamming:

\section{It [eating a razor clam] is way healthier than grabbing a burrito from a store. Also I have one of those heart rate monitor watch things, and so I monitored one clam dig and for every hour I was digging, I burned four hundred calories. And so a four hour commercial tide, I was like, "Yes!" (Youth)}

Furthermore, clams are a good storage food: they can be frozen, canned, or smoked to last well after the season is over. Other wellbeing benefits include self-sufficiency and the sense of efficacy and pride that comes from earning one's own income and providing one's own food:

\section{It helped me become independent, even at six years old I was buying my own school clothes. At age six I could dig 80 pounds of razor clams and we got 25 cents a pound. And I already knew the math and I could buy two pairs of Levis and two pairs of shoes with 20 dollars when I was six years old. (Elder)}

\section{Perceived risks}

Although our participants freely listed multiple, important benefits associated with their use of razor clams, they also noted a number of potential risks to both the resource and harvest. Some of the risks mentioned mapped well onto risks discussed in the Western scientific literature, whereas others were unique to our interviewees. We present both sets of risks below.

\section{Shared perceived risks}

Ocean change due to increased anthropogenic $\mathrm{CO}_{2}$ emissions (climate change and associated risks) were the most commonly identified risk to the razor clam resource, mentioned by 19 of 30 interview participants (Table 1). Participants identified climate change in general $(n=10)$, weather change $(n=2)$, sea level rise $(n=2)$, ocean acidification $(n=2)$, warming sea temperatures $(n$ $=2$ ), and glacier melting and reduced river flow $(n=1)$. Scientific studies similarly identify climate change as a risk to the razor clam resource system, but emphasize different processes than those mentioned by Quinault participants. For example, Weatherdon et al. (2016) used ecological modeling to demonstrate how changes in oceanic conditions, such as water temperature and salinity, may lead to future shifts in the razor clam geographic distribution or relative abundance.

Risk from HABs was the second most commonly mentioned risk to the razor clam resource, with 18 of 30 interview participants expressing concern (Table 1). Participants were concerned about toxin levels and related closures $(n=11)$, loss of income from closures $(n=5)$, decreased demand for razor clams because of fears of poisoning $(n=1)$, and temporal effects of harvest closures, such as the loss of "back to school" digs $(n=1)$. HABs are thoroughly discussed in the scientific literature as a risk to razor clam harvest because of the presence of toxins harmful to human health (Trainer and Bill 2004, Dyson and Huppert 2010, McCabe et al. 2016).

Pollution was identified as a risk to razor clam populations and harvest by 9 of 30 interview participants, as well as the scientific literature. Respondents were especially concerned about the possibility of oil spills associated with oil infrastructure development proposed for the central Washington coast. There are documented instances of clam mortality and fishery closures caused by oil spills in other parts of the world (Augenfeld et al. 1980, Loureiro et al. 2006). As is the case during a HAB, harvest of razor clams exposed to oil spills is prohibited to protect human health. Unlike HABs, oil spills may lead to razor clam mortality. Interview participants, as well as scientific literature, identified fecal contamination as another source of pollution (Friese 2016), which has led to harvest closures due to concerns for human health (Table 1, Fig. 4).

Geophysical and ecosystem changes, natural disasters, and disease were also identified as risks to the razor clam resource by both our interview participants and the scientific literature. Among the general risks from geophysical and ecosystem changes $(n=6)$, participants were most concerned about habitat damage to beaches, such as coastal erosion, dredging, accretion, depletion, driving vehicles on clam beds, and nonreservation digs damaging comanaged beaches. Interview participants also mentioned hypoxia and changing ocean currents as geophysical and ecosystem changes that pose risks to the razor clam resource. One participant mentioned storm surges as a natural disaster endangering the razor clam population and harvest. One study in the scientific literature identified a recent trend of increasing wave heights and winter storm severity on the Washington coast, and predicted increased wave action on Pacific coast beaches during winter months (Ruggiero et al. 2010). Several participants $(n=2)$ and the scientific literature named nuclear inclusion X, a disease that led to very high clam mortality in previous decades (Elston 1986), as a risk to razor clams (Table 1, Figure 4).

\section{Participant-specific perceived risks}

Our interview participants identified several additional perceived risks to razor clam populations and harvests beyond those mentioned in the scientific literature. Lack or loss of traditional knowledge was identified by 9 of 30 interview participants (Table 1). Participants were concerned about loss of harvesting knowledge for youth $(n=6)$, loss of conservation ethic $(n=2)$, and poor understanding of management $(n=1)$. Poor management practices were also mentioned by 9 of 30 participants. Respondents were concerned about overharvesting of natural resources, specifically clams and crabs, overharvest by nontribal diggers, and poaching. Six interviewees were concerned about the high cost of clamming gear as a barrier to their razor clam harvest. Two participants identified loss of access to clamming grounds as a potential risk, particularly beach closures associated with private coastal development. Two participants identified governance change as a potential risk, including loss of self-regulating status and loss of sovereignty (Table 1, Figure 4).

\section{Web-based tool}

Our respondents identified multidimensional benefits that the Quinault gain from their use of razor clams. They further identified complex risks associated with ocean change that are 
Table 1. Perceived risks identified by interviews. List of general risks, number of respondents $(n=30)$ who identified each risk, and some excerpts from interviews to demonstrate how the Quinault perceive these risks.

\begin{tabular}{|c|c|c|}
\hline Risk & $\begin{array}{l}\text { Number of } \\
\text { respondents } \\
\text { identifying risk }\end{array}$ & Excerpt \\
\hline Climate change & 19 & $\begin{array}{l}\text { "Climate change [is the biggest risk] ... and our wetlands are drying up now, all the creeks that } \\
\text { our fingerlings [juvenile salmon] need to survive ..." }\end{array}$ \\
\hline Harmful algal blooms & 18 & $\begin{array}{l}\text { "I think the risks are mostly financial because a lot of families depend on the extra money that } \\
\text { comes in to basically subsidize what they can't pay. Let's say a family needs to get school } \\
\text { clothes, sometimes they are on a fixed budget and they will blow their entire check on school } \\
\text { clothes. The clam digging, like I said, they used to use it at this time of year to make up for the } \\
\text { money they spent on their children and put it towards electrical and rent, and lights, and all the } \\
\text { stuff they have to take care of, food. It put a big damper on a lot people, people are struggling } \\
\text { because of it." }\end{array}$ \\
\hline Lack/loss of knowledge & 9 & $\begin{array}{l}\text { "I think as the younger generation, we are not very well set up for how our resources in the } \\
\text { future. The older generation does not tell the younger generation to respect the land as much. I } \\
\text { think we are losing that." }\end{array}$ \\
\hline $\begin{array}{l}\text { Management effectiveness and } \\
\text { compliance }\end{array}$ & 9 & $\begin{array}{l}\text { "I see there being a less amount of resources just because of - maybe not so much clamming } \\
\text { and stuff but like - poaching and overharvest and I think the big risk that we do to our own self } \\
\text { is that we are not very well educated with how everything works and I think it just comes out of } \\
\text { nowhere for most people. They don't really look at anything beyond their own needs." }\end{array}$ \\
\hline Pollution & 9 & $\begin{array}{l}\text { "... if they permit oil in Grays Harbor, which is supposed to be nine hundred thousand barrels } \\
\text { per ship ... [and] if one of those things spilled, it would be catastrophic. I don't think the clam } \\
\text { beaches would recover. I think the oil would run into the sand just like the pictures we've seen } \\
\text { in the Gulf [of Mexico]." }\end{array}$ \\
\hline
\end{tabular}

Geophysical/ecosystem 6

changes

Habitat damage 4

Loss of access 2

Challenges to sovereignty 2

Disease (Nuclear Inclusion X)

Natural disasters (storm surge)

Low participation in

commercial digs

\begin{abstract}
"Did you hear Seabrook was trying to close down [their beach] so we couldn't clam dig in front of their houses? Yeah. It makes their beach look dirty so they don't like it."

"I think the biggest risk is that we could lose our sovereignty, our right to exercise the treaty, I think that's the biggest risk our nation is facing. We are constantly getting attacked by outside entities trying to strip us of our rights. We shouldn't be allowed to do this or we shouldn't be allowed to do that, I think that's going to be our biggest threat, just from outsiders I guess you could say? That's going to be a constant threat, and it's always been a constant threat, as far as I can remember."
\end{abstract}

likely to impact their ability to continue enjoying those benefits. Based on these findings, we developed a web-based tool to allow users to learn more about the perceived risks and explore hypotheses on how each risk could impact the razor clam population and harvestability (see Appendix 5 for details). The web-based tool includes: (1) educational modules on the physical and biological processes behind each perceived risk, (2) a stagestructured razor clam population model, and (3) a simulation segment that allows users to explore the expected impacts of interacting risk scenarios on the razor clam population and harvest through processes such as mortality, density dependence, and fishery closures, including potential outcomes considering variation and uncertainty.

Tool users can explore the single or combined impacts of (1) $\mathrm{HABs}$, where the harvest rate is set to zero during harvest closures at user-specified frequencies and durations, but there is no impact on razor clam survival rates; (2) increasing wave heights and storm surges, which we modeled by reducing the survival of razor clam larvae and juveniles over time, (3) pollution and oil spills, modeled by reducing the survival of juvenile and adult razor clams over time, and (4) habitat destruction, which we equate to reduced beach capacity and modeled as density-dependent mortality among juvenile and adult razor clams. Users first see the deterministic, expected impact of a specific risk combination (Appendix 6, Fig. A6.1), and can then choose to include environmental variation (implemented by random variation on the number of prerecruits) to better reflect ecological uncertainties (Appendix 6, Fig. A6.2). Users can explore the expected average number of years with fishery management closures, the average number of years with fishery closures due to low razor clam abundance, and the average change in catch over the simulation period. The equilibrium assumption that underpins the tool allows one to explore expected relative changes to the population based on impacts from perceived risks, without the confounding influence of population disequilibrium as a starting condition.

Following our final field visit, during which a meeting with community members was dominated by questions about HABs 
Fig. 4. Comparison of risks to the razor clam (Siliqua patula) resource identified by members of the Quinault Indian Nation (left, blue) and non-Quinault scientists and natural resource managers (right, yellow), along with risks identified by both parties (middle, green). The order of risks is ranked first by the number of QIN members who mentioned each of the shared risks, and then the number of QIN members who mentioned each additional ecological and social risk.

\section{Quinault identified risks Shared Non-Quinault identified risks}

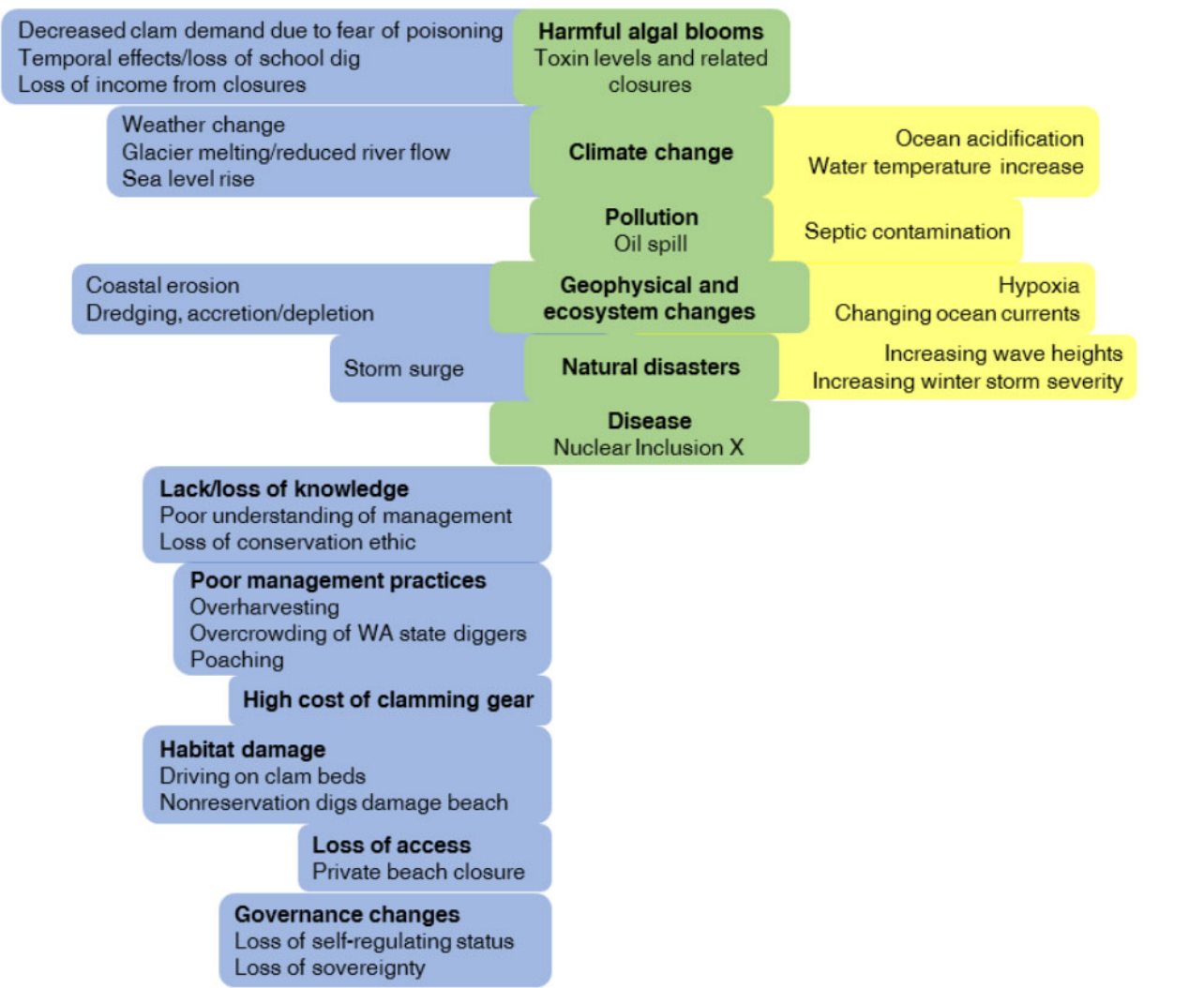

and how they impact razor clams, we added educational modules to the interactive web-based tool. Quinault members and Quinault Department of Natural Resources (QDNR) employees told us that the Quinault learn about risks to the razor clam population through word of mouth, observation of current events, and personal experiences, but have limited opportunities to learn about the science behind the perceived risks and their expected impacts. The education modules we developed partially address this gap. We have made the user interface for the tool publicly available at https://merrillrudd.shinyapps.io/razor clam pop so that Quinault resource managers and tribal members can access it for teaching, learning, and preparation for the future.

\section{Tool applications}

The "Explore risks" tab of the interactive tool allows the user to explore the expected impact of perceived risks on a hypothetical razor clam population. For example, the user can chose "Harmful algal blooms" to learn more about the expected impacted of a HAB-related fishery closure on the razor clam population. Although HABs result in the need for fishery closures due to toxins in the clams that are harmful to humans, the toxins do not affect the health of the razor clam itself. Therefore, fishery closures, every five years for example, would allow the population size to increase during the years without harvest and thus lead to population growth over a period of 10-20 years. However, with closures due to HABs every five years out of a simulated 20 years, the average percentage change in catch would decline by $13 \%$ because of zero harvest in four out of 20 years. Including a moderate level of variability in the system to represent uncertainty in environmental conditions could result in additional decline in catch simply because of variability in the number of razor clams available for harvest on the beaches, unrelated to management impacts of HABs.

The user can also explore the expected impact of multiple risks at once. Increasing wave heights due to storm surges and pollution and oil spills would be expected to impact razor clam mortality rates. Small declines in juvenile and adult survival rates would lead to significant losses in razor clam catch because of fewer razor clams available on the beaches. A $10 \%$ decrease in the adult survival rate would lead to an additional $4 \%$ decline in average catch over a 20 -year period, while a $10 \%$ decrease in the juvenile survival rate would lead to an additional $11 \%$ decline in average catch over that period. Habitat destruction was implemented as 
density-dependent mortality rates, and in this model a $10 \%$ reduction in habitat was associated with $20 \%$ declines in average catch. The percentages reported here are dependent on the assumed values for razor clam mortality rates and the strength of the density-dependent relationship, and although based on a literature review to obtain reasonable rates, are still likely to be inaccurate. The takeaway from these simulations is the expected directional impact of each risk on the razor clam population (increase or decrease in razor clam population size), the potential declines in catches that could occur because of density-dependent effects on beaches, and the uncertainty associated with environmental variability.

\section{DISCUSSION}

Razor clams are of central importance to the QIN because the harvest of razor clams provides a suite of economic benefits to the tribe. But respondents noted varied additional benefits as well. Consistent with Ostrom's (2009) conceptualization of SES, these include institutional benefits (harvesting and regulating the harvest reinforce institutions underpinning tribal sovereignty), and social capital benefits (harvesting and sharing clams builds and maintains community ties). Other benefits that depart from those on which SES frameworks focus also emerged from our participants' responses. Respondents pointed to the importance of razor clams to QIN cultural identity, as well as health and wellbeing benefits from harvesting and eating clams.

\section{The importance of culture}

Previous studies identified that historically razor clams were a critical food resource for the Quinault (Olson 1936) and there are references to clamming in Quinault myths (Livingston and Kahnweiler 1975). Our findings indicate that razor clams should be considered a cultural keystone species for the Quinault. Garibaldi and Turner (2004) define cultural keystone species as "...culturally salient species that shape in a major way the cultural identity of a people, as reflected in the fundamental roles these species have in diet, materials, medicine, and/or spiritual practices." Razor clams have a nonredundant role in Quinault society, similar to what is observed for other cultural keystone species such as cassava for the Guyanese Wapishana (Platten and Henfrey 2009) and red cedar for First Nations of British Columbia (Garibaldi and Turner 2004).

To support the assertion that razor clams should be considered a cultural keystone species for the Quinault, we show that culture is woven through many other classes of benefits and risks beyond our participants' direct discussion of Quinault identity. For example, intergenerational knowledge transfer during home use harvests create opportunities for sharing broader cultural knowledge as well as knowledge of razor clams. Traditional community or family meals that reinforce social ties often give razor clams pride of place on the menu; food can be a precursor to and reinforcer of shared culture (Anderson 2005). Similarly, the barter and exchange of resources including clams also reinforces traditional Quinault cultural norms of reciprocal gifting while reinforcing social cohesion.

Social-ecological systems theory has been criticized as glossing the specific - poorly specified, nonquantifiable social constructs like culture - at the expense of the general relationships between the biogeophysical, resource, user, and governance systems
(Stojanovic et al. 2016). In particular, Ostrom's (2009) framework and its applications have been criticized for conceptualizing humans' relationships to their environment as fundamentally concerned with managing resource use and neglecting the cultural roots of use and management practices (Fabinyi et al. 2014). Relatedly, work applying Ostrom's (2009) SES framework to fisheries has refined conceptualizations of SES benefits by parsing the "importance of the resource" (Ostrom 2009) into economic and cultural components (Basurto et al. 2013). Consistent with previous studies, culture and Quinault identity emerged as expected as important components of our participants' perceptions of the benefits and risks associated with razor clams and their use. Our findings reiterate the need to consider culture as both driving and impacting SES.

\section{The value of participatory research}

Including indigenous peoples as partners in the scientific process and coproducing knowledge can lead to benefits such as increased spatial resolution of data, extended temporal observations, and the formation of novel hypotheses (Huntington et al. 2011). It may also introduce information that challenges existing scientific norms and perceptions of how systems work, thereby progressing inquiry in novel and valuable ways. Our synthesis of interview data with information contained in the scientific literature suggests that razor clams and their harvest are subject to an array of risks. Interview participants indicated that primary risks to the ecological system surrounding razor clams include climate change, HABs, and pollution. Many of the risks identified by Quinault participants overlap with those identified in the peerreviewed Western scientific literature.

Importantly, interview participants also identified a number of risks to razor clams and their harvest that go beyond those identified by scientists. These risks included localized observations of habitat degradation, e.g., beach erosion and compaction, and the loss of harvesting knowledge among young people. Other studies suggest that traditional harvesting knowledge is closely linked to the practice of traditional skills, such as canoe-making (Brosi et al. 2007), but can also inform traditional resource management (Berkes 2012) and contribute to the preservation of biological diversity (Gadgil et al. 1993, Nabhan et al. 2002, Siebert and Belsky 2014). Thus, the loss of harvesting knowledge can catalyze changes not only to a human community but to the surrounding natural environment as well.

Interview respondents identified both economic and cultural losses as potential consequences of razor clam fishery closures. Although the effects of climate change on cultural expression are infrequently included in assessments of climate change impacts (Adger 1999), and consistent with our overall finding of culture as important emergent component of our target SES, the Quinault are concerned with the cultural impacts of harvest closure. This underlines the value of participatory, case-based approaches to research: local community members understand and communicate the risks they face in holistic and nuanced ways that ground an understanding of risk and vulnerability in placeand culture-specific knowledge and experience.

Furthermore, participatory, case-based research allows us to understand emergent dynamics in real time. For example, many of our respondents were preoccupied with the economic impacts of HABs and associated fisheries closures. Although respondents' 
focus on HABs is likely to have been a function of the timing of our research, HABs are a genuine risk, and science suggests that HAB-associated harvest closures are likely to be both less predictable and more frequent in the future (McCabe et al. 2016). Prior research demonstrates that elements of global change that can be seen or experienced are more likely to convince people change is happening, and that the experience of recent extremes compatible with predicted effects of global environmental change are more likely to be attributed to such change by the public (Demski et al. 2017).

Our findings also allowed us to identify vulnerabilities faced by the Quinault. Community vulnerability is grounded in deep connections to place and high levels of economic and cultural reliance on razor clams, especially for lower income community members, combined with remote location and a lack of economic alternatives. It is clear that the Quinault, like many similar communities, are especially vulnerable to ocean change (Maldonado et al. 2014). This is particularly true given the complexity of the risks identified by our respondents. The negative economic impacts of reduced harvest opportunities are relatively easy to predict, but the cultural impacts less so. It is not difficult to imagine how the risks identified by respondents might interact. For example, reduced availability of clams could mean reduced harvest opportunities, resulting in further loss of harvesting knowledge among youth. Were this to continue over time, it is possible that the loss of knowledge would result in reduced harvesting even if clam populations themselves rebound. Consistent with respondents' fears, this might have ramifications for Quinault identity, or even tribal sovereignty, as use of the resource declines and impingements on access go unchallenged.

\section{Opportunities to plan and adapt}

With our respondents' input, we identified a number of opportunities to address the vulnerabilities and risks that were identified in this study. These include educating community members about razor clam biology, the causes of HABs, and the mechanisms behind harvest closures; mitigating the economic effects of fishery closures; improving HAB information-sharing; and coordinated planning for future fishery closures.

Community members themselves identified the first set of opportunities: (1) improving the availability of Western scientific information on razor clam biology, and investigating mechanisms behind risks to clams and clam harvests and (2) sharing existing traditional knowledge within the community more widely. We address (1) in part via the educational modules included in the web-based tool. We have shared the tool with QIN biologists involved in managing the razor clam fishery, who plan to include the tool in their own outreach. Other fruitful approaches might include brief presentations by natural resource managers at community meetings, meals, or other events that include razor clams on the menu. Integrating this approach with stories, beach trips, or other opportunities for sharing by elders and others with traditional knowledge of razor clams and the wider coastal ecosystem could also help with the preservation and dissemination of traditional ecological knowledge. Improving community members' understanding of the fine-grained details of the resource system, especially in the context of ocean change, may help reinforce Quinault traditions while also helping community members make more informed choices about when to harvest and eat clams. In particular, individual choices to store more clams may reduce the experience of clam hunger or the rare instances of individuals choosing to clam despite dangerous toxin levels that do not allow harvest.

Our respondents expressed deep concerns about the economic impacts of fishery closures. Although dependence on clams and other marine resources is at the heart of the Quinault experience, simple strategies at both the community and individual level may help to mitigate economic losses. In particular, community- and individual-level income smoothing efforts might take increased uncertainty around the timing and frequency of HABs into account. Digs could be scheduled more frequently when HABs are less likely, for example, during winter months, and when toxin levels are low in clams; in addition, individuals digging clams for home use might be encouraged to structure their harvest and use of razor clams similarly. Although many of our respondents preferred fresh clams to stored clams, the educational efforts outlined above might also help encourage behavioral changes that incorporate ocean change into norms of resource use.

A number of respondents expressed discontent with existing razor clam markets and profits. The Quinault are already taking steps to address these issues: progress includes the recent certification of the fishery as a "Best Choice" by the Monterey Bay Aquarium's Seafood Watch program, permitting new tribal buyers to encourage price competition and a buying agreement with a highend national grocery chain. As existing seafood processing infrastructure is updated, the tribally owned Quinault Pride Seafoods might also consider manufacture, marketing, and sales of value-added products, e.g., clam chowder.

Finally, the Quinault are in the midst of a broad strategic planning initiative that seeks to address other sets of risks, e.g., tsunami danger. Understanding the risks and vulnerabilities outlined herein provide an opportunity to adopt and implement mitigative and adaptive efforts that are consistent and integrated with existing planning efforts.

\section{CONCLUSION}

Consistent with the complexity often uncovered in studies of social-ecological systems, we found that the Quinault perceive complex, interlinked benefits from and risks to the razor clam SES. Our synthesis of multiple data types, originating from both interviews and scientific literature, enabled us to explore complex, interacting risk scenarios and visualize their probable directional impacts on the razor clam population and harvest. Furthermore, interviews placed these risks in a valuable social and cultural context, while identifying possible adaptive strategies in the face of ocean change. This synthesis highlights how traditional and local ecological knowledge can be integrated with scientific information to identify how ocean change might affect coastal communities, and that how knowledge may be leveraged to help those communities prepare and adapt.

Responses to this article can be read online at: http://www.ecologyandsociety.org/issues/responses. php/10928 


\section{Acknowledgments:}

We thank the Quinault Indian Nation tribal members, government, biologists, and resource managers for their collaboration and welcoming spirit throughout our study and visits. We particularly thank Joe Schumacker, who acted as our primary local liaison and provided valuable support throughout. We acknowledge the National Science Foundation IGERT Program on Ocean Change, specifically Terrie Klinger, for research funding and support. We acknowledge our IGERT project advisors Eddie Allison and Marco Hatch for their feedback and insights in interdisciplinarity and working with a tribal organization. Finally, we thank our individual University of Washington departments and supervisors for supporting our efforts toward interdisciplinarity throughout our disciplinary PhD degrees.

\section{LITERATURE CITED}

Adger, W. N. 1999. Social vulnerability to climate change and extremes in coastal Vietnam. World Development 27(2):249-269. https://doi.org/10.1016/s0305-750x(98)00136-3

Anderson, E. N. 2005. Everyone eats: understanding food and culture. New York University Press, New York, New York, USA.

Anderson, J. W. 1999. The world is their oyster? Interpreting the scope of Native American off-reservation shellfish rights in Washington State. Seattle University Law Review 23(1):145-173.

Augenfeld, J. M., J. W. Anderson, D. L. Woodruff, and J. L. Webster. 1980. Effects of Prudhoe Bay crude oil-contaminated sediments on Protothaca staminea (Mollusca: Pelecypoda): hydrocarbon content, condition index, free amino acid level. Marine Environmental Research 4:135-143. https://doi. org/10.1016/0141-1136(80)90051-3

Basurto, X., S. Gelcich, and E. Ostrom. 2013. The socialecological system framework as a knowledge classificatory system for benthic small-scale fisheries. Global Environmental Change 23 (6):1366-1380. https://doi.org/10.1016/j.gloenvcha.2013.08.001

Bennett, N. J., J. Blythe, S. Tyler, and N. C. Ban. 2016. Communities and change in the Anthropocene: understanding social-ecological vulnerability and planning adaptations to multiple interacting exposures. Regional Environmental Change 16(4):907-926. https://doi.org/10.1007/s10113-015-0839-5

Berkes, F. 2012. Sacred ecology: traditional ecological knowledge and resource management. Routledge, New York, New York, USA.

Berkes, F., and D. Jolly. 2002. Adapting to climate change: socialecological resilience in a Canadian western Arctic community. Conservation Ecology 5(2):18. https://doi.org/10.5751/ES-00342-050218

Brosi, B. J., M. J. Ballick, R. Wlkow, R. Lee, M. Kostka, W. Raynor, R. Gallen, A. Raynor, and D. L. Ling. 2007. Cultural erosion and biodiversity: canoe-making knowledge in Pohnpei, Micronesia. Conservation Biology 21:875-879. https://doi. org/10.1111/j.1523-1739.2007.00654.X

Cinner, J. E., C. Folke, T. Daw, and C. C. Hicks. 2011. Responding to change: using scenarios to understand how socioeconomic factors may influence amplifying or dampening exploitation feedbacks among Tanzanian fishers. Global Environmental Change 21(1):7-12. https://doi.org/10.1016/j.gloenvcha.2010.09.001

Collins, S. L., S. R. Carpenter, S. M. Swinton, D. E. Orenstein, D. L. Childers, T. L. Gragson, N. B. Grimm, J. M. Grove, S. L. Harlan, J. P. Kaye, A. K. Knapp, G. P. Kofinas, J. J. Magnuson, W. H. McDowell, J. M. Melack, L. A. Ogden, G. P. Robertson, M. D. Smith, and A. C. Whitmer. 2011. An integrated conceptual framework for long-term social-ecological research. Frontiers in Ecology and the Environment 9(6):351-357. https://doi. org/10.1890/100068

Cornell, S., and J. P. Kalt. 1998. Sovereignty and nation-building: the development challenge in Indian Country today. American Indian Culture and Research Journal 22(3):187-214. https://doi. org/10.17953/aicr.22.3.1v45536553vn7j78

Demski, C., S. Capstick, N. Pidgeon, R. G. Sposato, and A. Spence. 2017. Experience of extreme weather affects climate change mitigation and adaptation responses. Climatic Change 140 (2):149-164. https://doi.org/10.1007/s10584-016-1837-4

Dolan, A. H., and I. J. Walker. 2006. Understanding vulnerability of coastal communities to climate change related risks. Journal of Coastal Research 3(SI 39):1316-1323.

Dyson, K., and D. D. Huppert. 2010. Regional economic impacts of razor clam beach closures due to harmful algal blooms (HABs) on the Pacific coast of Washington. Harmful Algae 9(3):264-271. https://doi.org/10.1016/j.hal.2009.11.003

Elston, R. A. 1986. An intranuclear pathogen [nuclear inclusion $\mathrm{X}$ (NIX)] associated with massive mortalities of the Pacific razor clam, Siliqua patula. Journal of Invertebrate Pathology 47 (1):93-104. https://doi.org/10.1016/0022-2011(86)90167-9

Epstein, G., J. M. Vogt, S. K. Mincey, M. Cox, and B. Fischer. 2013. Missing ecology: integrating ecological perspectives with the social-ecological system framework. International Journal of the Commons 7(2):432-453. https://doi.org/10.18352/ijc.371

Evans, L. S., C. C. Hicks, P. Fidelman, R. C. Tobin, and A. L. Perry. 2013. Future scenarios as a research tool: investigating climate change impacts, adaptation options and outcomes for the Great Barrier Reef, Australia. Human Ecology 41(6):841-857. https://doi.org/10.1007/s10745-013-9601-0

Fabinyi, M., L. Evans, and S. J. Foale. 2014. Social-ecological systems, social diversity, and power: insights from anthropology and political ecology. Ecology and Society 19(4):28. https://doi. org/10.5751/ES-07029-190428

Gadgil, M., F. Berkes, and C. Folke. 1993. Indigenous knowledge for biodiversity conservation. Ambio 22(2-3):151-156.

Garibaldi, A., and N. Turner. 2004. Cultural keystone species: implications for ecological conservation and restoration. Ecology and Society 9(3):1. https://doi.org/10.5751/ES-00669-090301

Gustanski, J. A., and D. Scarsella. 2015. Economic impacts of crude oil transport on the Quinault Indian Nation and the local economy. Resource Dimensions, Gig Harbor, Washington, USA.

Hauser, D. D. W., E. D. Tobin, K. M. Feifel, V. Shah, and D. M. Pietri. 2016. Disciplinary reporting affects the interpretation of climate change impacts in global oceans. Global Change Biology 22(1):25-43. https://doi.org/10.1111/gcb.12978 
Hinkel, J., P. W. G. Bots, and M. Schlüter. 2014. Enhancing the Ostrom social-ecological system framework through formalization. Ecology and Society 19(3):51. https://doi.org/10.5751/ES-06475-190351

Holling, C. S. 2001. Understanding the complexity of economic, ecological, and social systems. Ecosystems 4(5):390-405. https:// doi.org/10.1007/s10021-001-0101-5

Huntington, H. P., S. Gearheard, A. R. Mahoney, and A. K. Salomon. 2011. Integrating traditional and scientific knowledge through collaborative natural science field research: identifying elements for success. Arctic 64(4):437-445. https://doi. org/10.14430/arctic4143

James Jr., J. E., and L. A. Chubby. 2002. Quinault. Pages 99-118 in J. Wray, editor. Native peoples of the Olympic Peninsula: who we are. University of Oklahoma Press, Norman, Oklahoma, USA.

Kittinger, J. N., E. M. Finkbeiner, E. W. Glazier, and L. B. Crowder. 2012. Human dimensions of coral reef social-ecological systems. Ecology and Society 17(4):17. https://doi.org/10.5751/ ES-05115-170417

Lassuy, D., and D. Simons. 1989. Species profiles: life histories and environmental requirements of coastal fishes and invertebrates (Pacific Northwest)--Pacific Razor Clam. U.S. Fish and Wildlife Service Biological Report 82(11.89). TR EL-82-4. U.S. Army Corps of Engineers, Vicksburg, Mississippi, USA.

Livingston, F., and W. S. Kahnweiler. 1975. Traditions of the Quinault Indians. Revised edition. Pages 77-132 in Memoirs of the American Museum of Natural History. American Museum of Natural History, New York, New York, USA. (Original work published 1902).

Loureiro, M. L., A. Ribas, E. López, and E. Ojea. 2006. Estimated costs and admissible claims linked to the Prestige oil spill. Ecological Economics 59(1):48-63. https://doi.org/10.1016/j. ecolecon.2005.10.001

Maldonado, J. K., C. Shearer, R. Bronen, K. Peterson, and H. Lazrus. 2014. The impact of climate change on tribal communities in the US: displacement, relocation, and human rights. Pages 93-106 in J. K. Maldonado, B. Colombi, and R. Pandya, editors. Climate change and Indigenous Peoples in the United States: impacts, experiences and actions. Springer, Cham, Switzerland. https://doi.org/10.1007/978-3-319-05266-3 8

McCabe, R. M., B. M. Hickey, R. M. Kudela, K. A. Lefebvre, N. G. Adams, B. D. Bill, F. M. D. Gulland, R. E. Thomson, W. P. Cochlan, and V. L. Trainer. 2016. An unprecedented coastwide toxic algal bloom linked to anomalous ocean conditions. Geophysical Research Letters 43(19):10,366-10,376. https://doi. org/10.1002/2016GL070023

McMillan, H. 1924. The life-history and growth of the razor clam. 34th Annual Report. Washington Department of Fisheries, Olympia, Washington, USA.

Nabhan, G. P., P. Pynes, and T. Joe. 2002. Safeguarding species, languages, and cultures in the time of diversity loss: from the Colorado Plateau to global hotspots. Annals of the Missouri Botanical Garden 89(2):164-175. https://doi.org/10.2307/3298561
Nickerson, R. 1975. A critical analysis of some razor clam (Siliqua patula) populations in Alaska. Alaska Department of Fish and Game, Juneau, Alaska, USA.

Olson, R. L. 1936. Quinault Indians. Pages 38-39 in University of Washington Publications in Anthropology. Volume 6 No. 1. University of Washington Press, Seattle, Washington, USA.

Ostrom, E. 2009. A general framework for analyzing sustainability of social-ecological systems. Science 325:419-422. https://doi.org/10.1126/science.1172133

Ostrom, E., and M. Cox. 2010. Moving beyond panaceas: a multitiered diagnostic approach for social-ecological analysis. Environmental Conservation 37(4):451-463. https://doi.org/10.1017/ $\underline{\mathrm{S} 0376892910000834}$

Petheram, L., K. K. Zander, B. M. Campbell, C. High, and N. Stacey. 2010. 'Strange changes': Indigenous perspectives of climate change and adaptation in NE Arnhem Land (Australia). Global Environmental Change 20(4):681-692. https://doi. org/10.1016/j.gloenvcha.2010.05.002

Platten, S., and T. Henfrey. 2009. The cultural keystone concept: insights from ecological anthropology. Human Ecology 37 (4):491-500. https://doi.org/10.1007/s10745-009-9237-2

Porter, F. W. 1990. In search of recognition: federal Indian policy and the landless tribes of Western Washington. American Indian Quarterly 14(2):113-132. https://doi.org/10.2307/1185052

Ruggiero, P., P. D. Komar, and J. C. Allan. 2010. Increasing wave heights and extreme value projections: the wave climate of the U. S. Pacific Northwest. Coastal Engineering 57(5):539-552. https:// doi.org/10.1016/j.coastaleng.2009.12.005

Schwarz, A. M., C. Béné, G. Bennett, D. Boso, Z. Hilly, C. Paul, R. Posala, S. Sibiti, and N. Andrew. 2011. Vulnerability and resilience of remote rural communities to shocks and global changes: empirical analysis from Solomon Islands. Global Environmental Change-Human and Policy Dimensions 21 (3):1128-1140. https://doi.org/10.1016/j.gloenvcha.2011.04.011

Shaw, A., S. Sheppard, S. Burch, D. Flanders, A. Wiek, J. Carmichael, J. Robinson, and S. Cohen. 2009. Making local futures tangible-synthesizing, downscaling, and visualizing climate change scenarios for participatory capacity building. Global Environmental Change 19(4):447-463. https://doi. org/10.1016/j.gloenvcha.2009.04.002

Siebert, S. F., and J. M. Belsky. 2014. Historic livelihoods and land uses as ecological disturbances and their role in enhancing biodiversity: an example from Bhutan. Biological Conservation 177:82-89. https://doi.org/10.1016/j.biocon.2014.06.015

Silvern, S. E. 1999. Scales of justice: law, American Indian treaty rights and the political construction of scale. Political Geography 18(6):639-668. https://doi.org/10.1016/S0962-6298(99)00001-3

SocioCultural Research Consultants LLC. 2016. Dedoose Version 7.0.23, web application for managing, analyzing, and presenting qualitative and mixed method research data. SocioCultural Research Consultants LLC, Manhattan Beach, California, USA.

Stojanovic, T., H. M. McNae, P. Tett, T. W. Potts, J. Reis, H. D. Smith, and I. Dillingham. 2016. The "social" aspect of social- 
ecological systems: a critique of analytical frameworks and findings from a multisite study of coastal sustainability. Ecology and Society 21(3):15. https://doi.org/10.5751/es-08633-210315

Swinomish Indian Tribal Community. 2010. Swinomish climate change initiative climate adaptation action plan. La Conner, Washington, USA.

Tansey, J., J. Carmichael, R. VanWynsberghe, and J. Robinson. 2002. The future is not what it used to be: participatory integrated assessment in the Georgia Basin. Global Environmental Change 12(2):97-104. https://doi.org/10.1016/S0959-3780(02)00011-0

Trainer, V. L., and B. D. Bill. 2004. Characterization of a domoic acid binding site from Pacific razor clam. Aquatic Toxicology 69 (2):125-132. https://doi.org/10.1016/j.aquatox.2004.04.012

Tschakert, P. 2007. Views from the vulnerable: understanding climatic and other stressors in the Sahel. Global Environmental Change 17(3-4):381-396. https://doi.org/10.1016/j.gloenvcha.2006.11.008

Turner, N. J., and H. Clifton. 2009. "It's so different today": climate change and indigenous lifeways in British Columbia, Canada. Global Environmental Change 19(2):180-190. https://doi. org/10.1016/j.gloenvcha.2009.01.005

van Aalst, M. K., T. Cannon, and I. Burton. 2008. Community level adaptation to climate change: the potential role of participatory community risk assessment. Global Environmental Change 18(1):165-179. https://doi.org/10.1016/j.gloenvcha.2007.06.002

Viera, A. J., and J. M. Garrett. 2005. Understanding interobserver agreement: the kappa statistic. Family Medicine 37(5):360-363.

Walker, B., C. Holling, S. R. Carpenter, and A. Kinzig. 2004. Resilience, adaptability and transformability in social-ecological systems. Ecology and Society 9(2):5. https://doi.org/10.5751/ ES-00650-090205

Weatherdon, L. V., Y. Ota, M. C. Jones, D. A. Close, and W. W. L. Cheung. 2016. Projected scenarios for coastal First Nations' fisheries catch potential under climate change: management challenges and opportunities. PLoS ONE11(1):e145285. https:// doi.org/10.1371/journal.pone.0145285

Wolf, J., I. Allice, and T. Bell. 2013. Values, climate change, and implications for adaptation: evidence from two communities in Labrador, Canada. Global Environmental Change 23(2):548-562. https://doi.org/10.1016/j.gloenvcha.2012.11.007

Wyer, H. 2013. Pacific Razor clam Siliqua patula. Monterey Bay Aquarium Seafood Watch. Monterey, California, USA. 
Appendix 1. Key informant interview script.

\section{Introduction}

We'd like to speak with you today about the Quinault Indian Nation and their harvest and use of razor clams. Please bear with us as we follow the script we have prepared. Some questions may seem repetitive; if at any time you feel you have already answered a question, please feel free to refer to an earlier answer or let us know that you have already covered that topic.

\section{Neutral prompts:}

Can you help me understand ?

Can you say anything else about ?

Can you tell me more about ?

(In response to IDK) If you had to guess?

\section{Background/General information}

What do you think razor clams mean to the Quinault?

How many Quinault harvest clams?

Is there a subgroup within the Quinault Nation who harvests most of the clams?

Prompt: Do some people collect more clams than others? What types of people?

Is there a subgroup within the Quinault Nation who eats most of the clams?

Prompt: Do some people eat more clams than others? What types of people?

A Are there other subgroups within the Quinault Nation that we should be sure to speak with?

Prompt: Do some people use clams differently than others in ways we haven't already discussed? Who?

\section{Economics (for seafood processors only)}

$\checkmark$ Who buys razor clams on the beach?

Prompt: Are there any other buyers?

$\checkmark$ Where do the clams go next?

○ Who buys the clams from the processor(s)?

Prompt: What are the clams used for? (Bait? Food?)

○ho decides the price that the clammers get for the clams? 
What influences the price of clams?

Have you observed any trends in razor clam price?

Prompt: What are they?

Who owns the processor (Quinault Pride Seafoods)?

Who has a share in the profits from the processor (Quinault Pride Seafoods)?

Do you actively seek and/or stimulate new markets for razor clams?

Prompt: How?

\section{Razor clam governance}

$\bigcirc$ Is there an individual (or more than one) in charge of razor clam management for the Quinault Nation?

Prompt: Who?

○ How does the Quinault Nation make decisions about razor clam harvests?

○ How do Quinault managers and decision-makers work with non-tribal razor clam governance?

$\checkmark$ How does the Quinault Indian Nation allocate their portion of the razor clam harvest between subsistence and commercial users?

Do the Quinault lobby to influence razor clam management or legislation?

Prompt: How?

○ Are there any NGOs involved in the Quinault razor clam fishery?

Prompt: In what capacity?

○ How does the Quinault Nation work with other tribes on clam and marine issues?

$\square$ If the Quinault Nation decided that they wanted to change the way razor clam harvest decisions are made, could they?

Prompt: How?

\section{Leadership}

$\checkmark$ Is there a Quinault tribal leader for razor clams or razor clam harvests in addition to the person in charge of management that we discussed earlier?

\section{Monitoring and enforcement}


$\checkmark$ How does the Quinault Nation monitor the clam harvest?

$\bigcirc$ How does the Quinault Nation enforce harvest levels?

Prompt: How do you think that works?

\section{Property rights}

$\checkmark$ Within the Quinault Indian Nation, who is allowed to access the clamming grounds?

Prompt: Do different subgroups harvest in specific areas? For example, an area reserved for elders?

Are there access issues that make it difficult for individuals or subgroups to access the clamming grounds?

- Who has the right to harvest razor clams?

Prompt: What does that mean in practice?

○ How does the permitting process for gathering razor clams work?

\section{Conflict}

○ In general, what happens when tribal razor clam needs conflict with non-tribal razor clam management?

○ Are there ever conflicts between tribal clammers?

Prompt: What happens then?

Are there ever conflicts between tribal and non-tribal clammers?

Prompt: What happens then?

\section{Historical trends}

$\checkmark$ Introduce timeline. How has the use and importance of razor clams to the Quinault changed over time?

Prompts: Can you remember any specific events or changes having to do with razor clams? What did people do then?

\section{Socioecological trends}

$\checkmark$ What comes to mind when you think about razor clams and razor clam harvests in recent years?

D Do you observe any changes?

Prompt: What are they? 
Where do you observe these changes? Refer to map

$\bigcirc$ How do you explain the changes you observe?

$\bigcirc$ Do you expect future changes to do with razor clams?

Prompts: What changes do you think you'll see? How do you think people will deal with those changes?

- What are the principal risks facing razor clams and the harvest?

\section{Problem-solving resources}

$\checkmark$ What external resources are available to the Quinault Nation to help address risk and change in the context of razor clams?

\section{Conclusion}

$\checkmark$ Is there anything you didn't get a chance to talk about that you think we should cover, or anything else that you'd like to add?

○ If you are interested, we'd be happy to share a document outlining our findings at the conclusion of our study. Would you like us to share our findings with you? How would you like us to contact you? 
Appendix 2. Group interview script.

\section{Introduction}

We are a team of graduate students from the University of Washington who are partnering with the Quinault Indian Nation to conduct a series of interviews about razor clams and their uses.

We have two broad research objectives:

1. To document the cultural, social, and economic importance of razor clams to the Quinault;

2. To investigate how razor clam harvests may be challenged by changes in ocean conditions.

We hope that this research will provide the Quinault Indian Nation with useful new information on connections between razor clams, razor clam harvests, and the community. And so today we'd like to speak with you today about the Quinault Indian Nation and their harvest and use of razor clams.

Please bear with us as we follow the script we have prepared. Some questions may seem repetitive; if at any time you feel you have already answered a question, please feel free to refer to an earlier answer or let us know that you have already covered that topic. We strive to maintain the confidentiality of the information you share with us. We would greatly appreciate your help by not identifying one another if you discuss today's interview outside of this room.

\section{Neutral prompts:}

Can you help me understand ?

Can you say anything else about

Can you tell me more about ?

(In response to IDK) If you had to guess?

\section{Opener}

$\circ$ Can you tell me a little bit about the Quinault and razor clams?

\section{Historical trends}

Introduce timeline.

○ How has the use and importance of razor clams to the Quinault changed over time?

Prompt: Can you remember any specific events or specific times?

\section{Seasonal trends}

Introduce seasonal cycle graphic.

oWe'd like to map together what you do over the course of the year. This is the cycle of the seasons. Let's start with when you gather clams. When are razor clams important? 
○hat comes after razor clams? Facilitate working through the seasonal cycle together.

\section{Personal history}

○ What can you tell us about your own history of clamming?

Prompts:

When did you start clamming?

What do you do with the clams that you harvest?

\section{Introduce map.}

○ Where do you go clamming?

\section{Information sharing and transfer}

○ In general, who do you talk about clams and clam harvests with?

Prompt: Who taught or teaches you about razor clams?

Prompt: Do you teach others about razor clams?

Is there someone you consider a leader for razor clams or razor clam harvests?

\section{Other uses and well-being}

$\checkmark$ Are there activities in your life in addition to clamming that involve razor clams?

Do razor clams have any other special significance for you?

Prompt: You know, spending time with family, spending time in nature, your health and well-being, special celebrations?

\section{Socioecological trends}

$\checkmark$ What comes to mind when you think about razor clams and razor clam harvests in recent years?

Do you observe any changes?

Prompt: What are they?

$\square$ Where do you observe these changes? Refer to map

Prompt: How do you explain the changes you observe?

○ Are there any times when you have wanted to harvest razor clams but have not been able to?

Prompts:

What was that like?

What did you do?

How long did you think it would take before you could go clamming again? 
Ask if not already addressed in the above:

○ Do you have experience with red tides?

○ Do you think you'll see future changes in razor clams or your harvest?

Prompt:

What changes do you think you'll see?

Introduce participatory ranking of risks.

What risks do you think face the clam fishery?

In general, what risks face the Quinault community?

O Which of these risks do you think is most important?

$\bigcirc$ Is there a group of people in your community who are most vulnerable to these risks?

\section{Conclusion}

$\bigcirc$ Is there anything else you'd like to share about what you've observed over time in local waters?

O Is there anything else you'd like to share about what you've observed over time in the Quinault Nation?

O If you are interested, we'd be happy to share a document outlining our findings at the conclusion of our study. Would you like us to share our findings with you? How would you like us to contact you?

\section{Group interviews: Written supplement}

Age:

Employment or source of income:

What kind of clam harvesting do you participate in? Please circle all that apply.

Subsistence Commercial

Who do you go clamming with?

Family Friends Youth Elders Other: 
On average, how many times per year do you go clamming during:

Subsistence tides:

Commercial rides:

On average, how much time do you spend clamming during a single:

Subsistence tide:

Commercial tide:

What part of your income comes from razor clams? Please circle one.
None/ Almost none
A little
About half
A lot
Almost all

What part of your diet is made up of razor clams? Please circle one.
None/ Almost none
A little
About half
A lot
Almost all

What do you do with the clams that you harvest during a subsistence tide?

Percent kept

Percent given away

Who do you share your clams with?

How do you harvest clams? Please circle one.

Shovel Gun Other

Where did you get your equipment? Please circle one.
Inherited
Gifted
Bought used
Bought new

Please use the remaining space to tell us anything else you feel is important but didn't yet have a chance to share 
Appendix 3. Coding scheme.

Title

Affect

Outcomes

\section{Ecological performance Social performance}

Human health outcomes

Cultural outcomes

Sovereignty/self-determination outcomes

Social outcomes

Economic outcomes Livelihood outcomes

\section{Resource System}

Predictability of system dynamics

Ecological interactions with other

species

\section{Related Ecosystems}

Flows into and out of focal SES

Climate/physical patterns

Pollution patterns

\section{Users}

\section{Socioeconomic attributes of users}

Description

Emotional content.

Negative emotional content.

Positive emotional content.

From Ostrom (2009). A General Framework for Analyzing the Sustainability of Social-Ecological Systems.

Harvest quotas, harvest, abundance, etc. From Ostrom (2009). A General Framework for Analyzing the Sustainability of SocialEcological Systems.

From Ostrom (2009). A General Framework for Analyzing the Sustainability of Social-Ecological Systems.

\section{Emergent code}

Emergent code

Statements about money in the context of the harvest.

Includes food security

Predidtability of conditions, clam populations or harvest. From Ostrom (2009). A General Framework for Analyzing the Sustainability of Social-Ecological Systems.

Within the target SES: predation, food species, etc, not human mediated interactions. For interactions through other harvests or other SESs see Externalities to Other SESs.

From Ostrom (2009). A General Framework for Analyzing the Sustainability of Social-Ecological Systems.

Connections to other SES's, including other harvests, other communities, etc., but not used for phenomena that affect multiple SES's (e.g. climate change). From Ostrom (2009). A General Framework for Analyzing the Sustainability of Social-Ecological Systems.

Loosely defined - changes to long-term weather patterns, natural systems, or direct references to climate. From Ostrom (2009). A General Framework for Analyzing the Sustainability of Social-Ecological Systems.

Both causes and effects of pollution. From Ostrom (2009). A General Framework for Analyzing the Sustainability of Social-

Ecological Systems.

From Ostrom (2009). A General Framework for Analyzing the Sustainability of Social-Ecological Systems.

Any reference to characteristics of users. From Ostrom (2009). A General Framework for Analyzing the Sustainability of SocialEcological Systems. 


\section{History of use}

\section{Importance of resource}

Norms/social capital

Risks

Norms

Risks to QIN as a whole

Risk to razor clam populations

Risks to individual QIN members

Risks to razor clam harvests

Adaptation/mitigation

Current adaptation/mitigation

Future suggestions
Limited to use of razor clams only, but may be individual, tribal or regional history of use From Ostrom (2009). A General Framework for Analyzing the Sustainability of Social-Ecological Systems.

Any reference to the importance of razor clams (livelihoods, health, food, etc.) to users (individuals, subgroups, or the tribe as a whole). From Ostrom (2009). A General Framework for Analyzing the Sustainability of Social-Ecological Systems.

From Ostrom (2009). A General Framework for Analyzing the Sustainability of Social-Ecological Systems.

Social connections or relationships and their importance to individuals or the tribe as a whole. From Ostrom (2009). A General Framework for Analyzing the Sustainability of Social-Ecological Systems.

Agreed upon but informal rules or procedures or usual ways of doing things. From Ostrom (2009). A General Framework for Analyzing the Sustainability of Social-Ecological Systems.

Specifically looking forward into the future.

For adaptation or mitigation, but also for marketing and management 
Appendix 4. Full conceptual model of the social-ecological system.
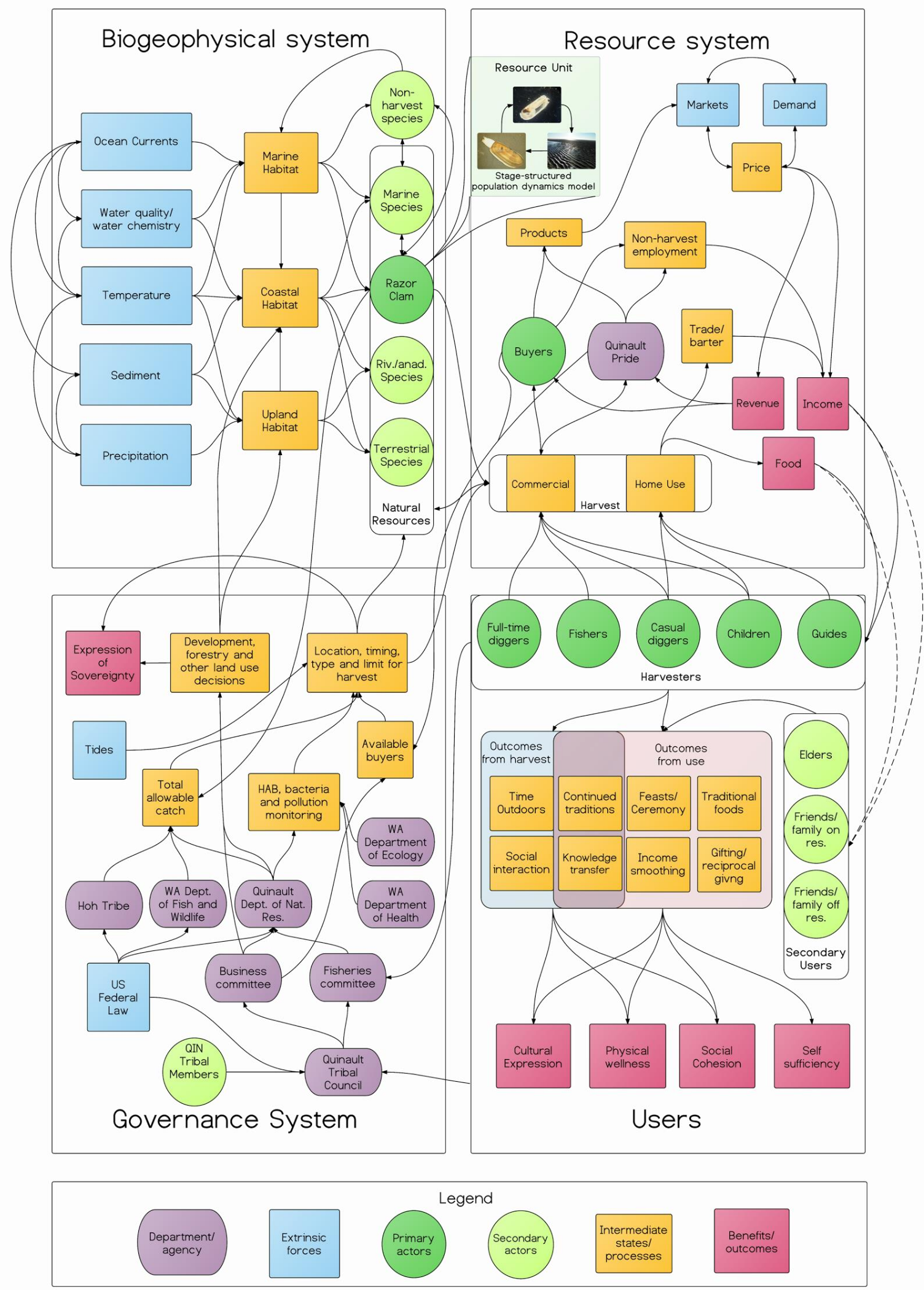
Appendix 5. Specifics of the razor clam population model.

The stage-based razor clam population model was designed to explore the direct impact of perceived risks on the clam population, not to represent the exact magnitude of change or to account for spatial processes (i.e., effects on populations on individual beaches).

The stage-based razor clam model consists of one population with pre-recruit and recruit stages; we define pre-recruits as razor clams below preferable size and recruits as razor clams above preferable size. Preferable size is approximately 3 inches, corresponding with the size that clams tend to "show" via dimples in the sand (WDFW, 2018). We used these stages in a Lefkovitch matrix assuming a 95\% probability that pre-recruits move to the recruit stage annually and assuming recruits remain in the recruit stage for three years, at which point they die (from either natural causes or harvest). Recruit survival is density-dependent, so that the estimated razor clam population size is constrained by beach capacity (Figure D1). We assumed female razor clams represent $50 \%$ of the population and that each female produces 8 million eggs per year (McMillan 1924). We assumed the survival rate of recruits to be 0.40 , the estimated survival rate for adult razor clams (Nickerson 1975). We used a pre-recruit survival rate of 0.089 , close to the estimated juvenile survival rate of 0.90 from Nickerson (1975), and a survival rate of eggs of $2.9 \mathrm{e}^{-6}$ (adjusted $a d$ hoc to obtain reasonable population dynamics). Because the razor clam harvests appear to be sustainable at a $30 \%$ harvest rate, and given that decades-old studies on razor clam survival rates are not in agreement on survival at each stage, we tuned the survival rates of eggs and pre-recruits to represent a population in sustainable equilibrium, maintaining the assumption that recruit survival is higher than pre-recruit survival. 


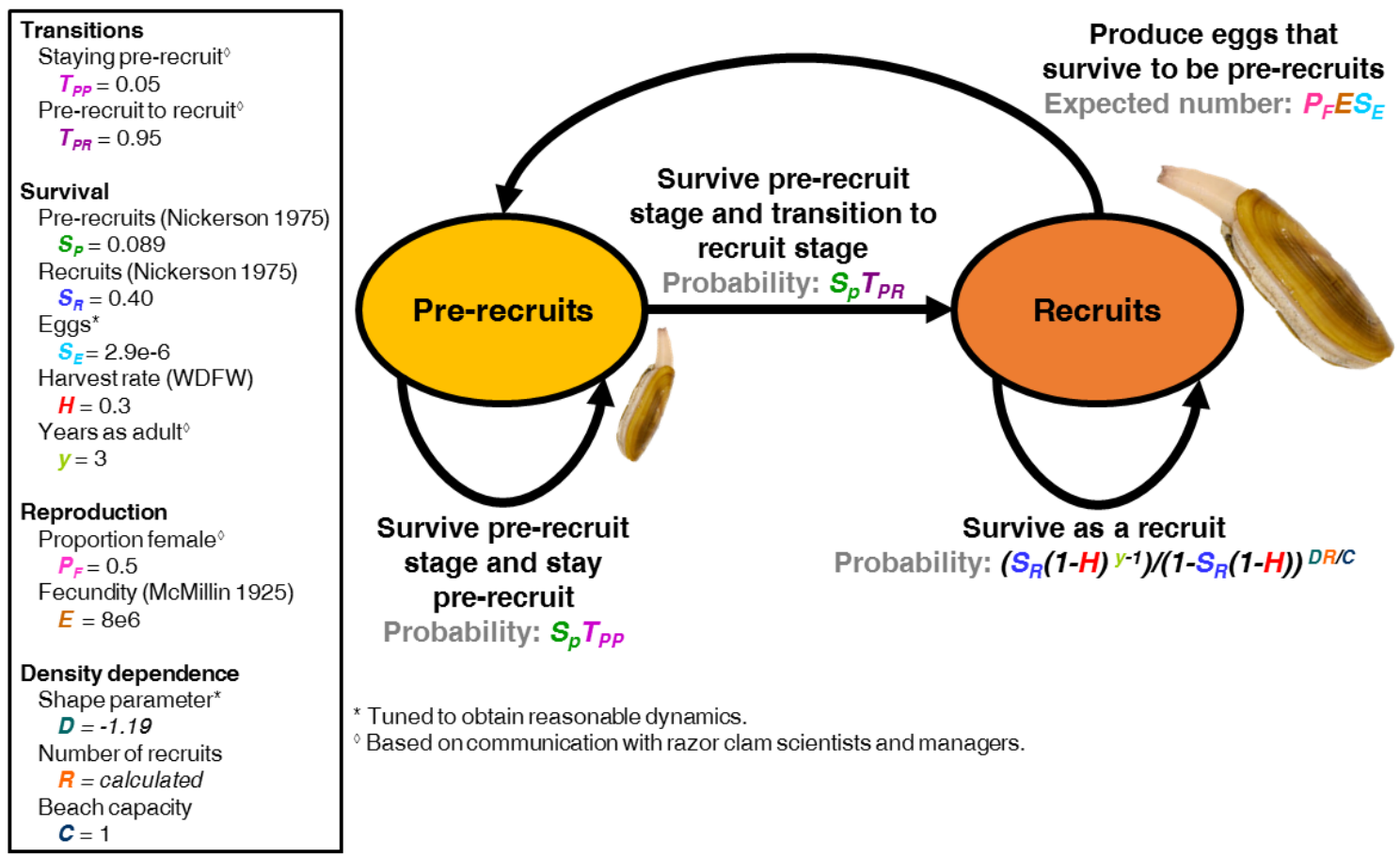

Figure A5.1. Stage-based razor clam population model used to simulate potential impacts of the Quinault's perceived risks. We show transition probabilities between the pre-recruit and recruit stages, survival rates at each stage, reproduction parameters, and parameter values for densitydependence and beach capacity. 


\section{Appendix 6. Overview of the interactive web-based tool generated to explore perceived risks to razor clams.}

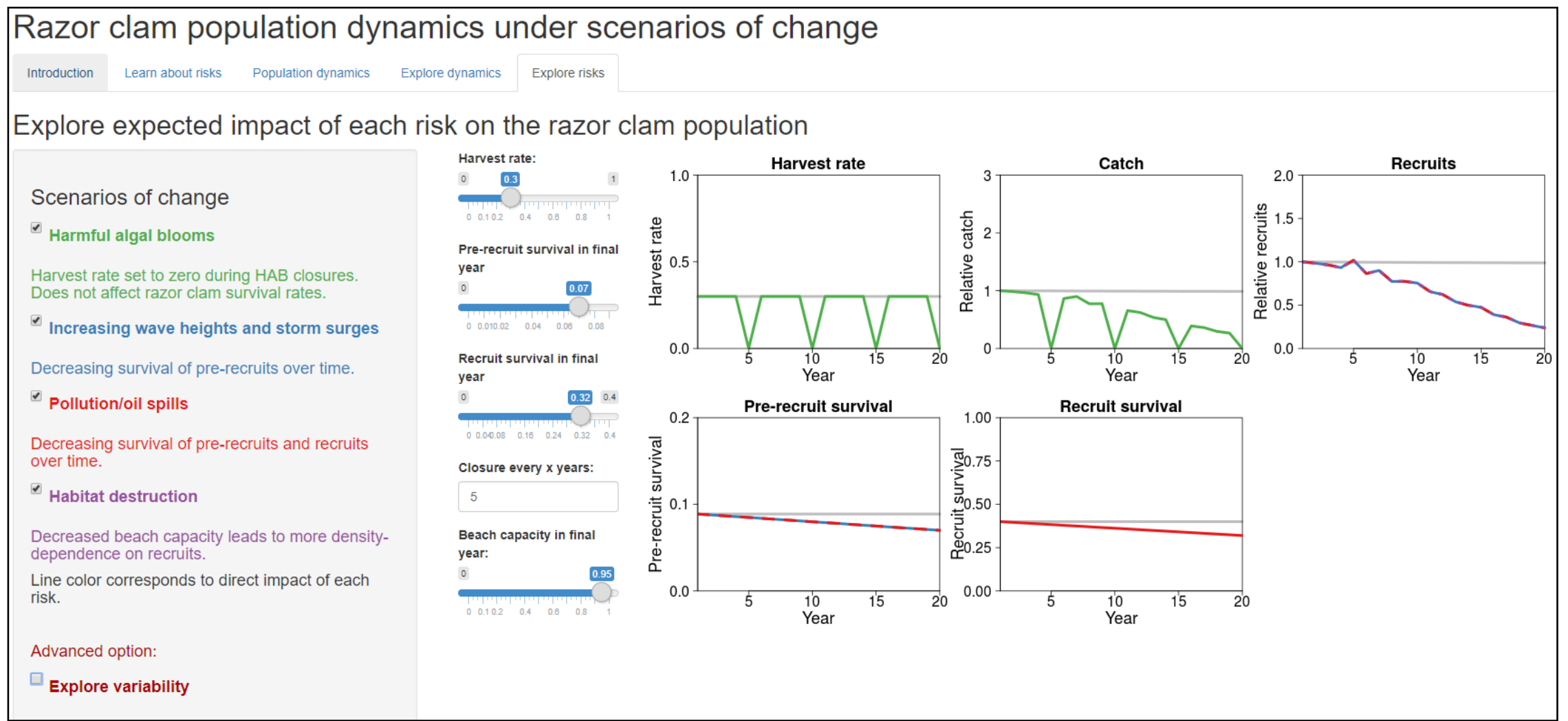

Figure A6.1. Screenshot of the shiny app (https://merrillrudd.shinyapps.io/razor_clam_pop/) "Explore risks" tab where the user can examine the expected impact of any combination of harmful algal blooms, increasing wave heights and storm surge, pollution and oil spills, and habitat destruction on harvest rate, catch, and recruits as implemented via harvest closures, changing survival rates, and beach capacity. 


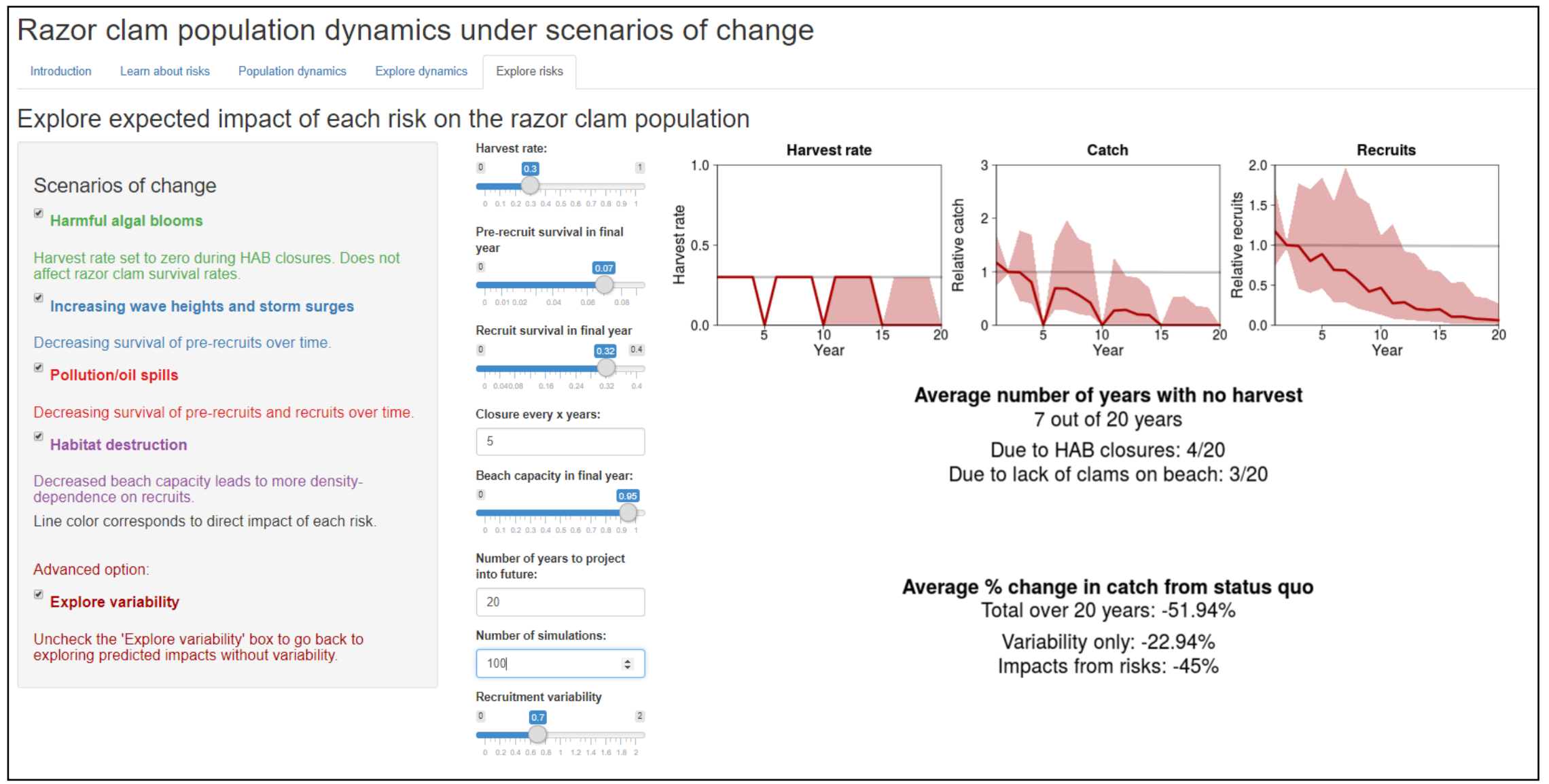

Figure A6.2. Screenshot of the shiny app (https://merrillrudd.shinyapps.io/razor_clam_pop/) "Explore risks" tab where the user can explore variability on top of the expected impact of any combination of harmful algal blooms, increasing wave heights and storm surge, pollution and oil spills, and habitat destruction by including stochastic iterations of simulated populations with lognormally distributed variability on annual recruitment. The user can explore the average number of years with no harvest and average percent change in catch from equilibrium without variability across 100 simulations of projected populations. 